\title{
Seroprevalence of pathogenic Leptospira serovars in hunting dog in Bosnia
} and Herzegovina

\author{
A. Ćutuk*, B. Čengić, L. Velić, A. Dovč, R. Lindtner Knific, E. Šaljić and P. \\ Bejdić
}

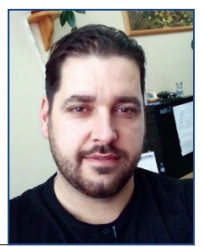

\begin{abstract}
Leptospirosis is an acute, subacute and chronical contagious disease of animals and humans. Causative agents of this disease belong to the genus Leptospira, family Leptospiraca. As a disease of wild animals, leptospirosis is widespread through Europe. Certain wild animals (rodents, fox and wild boars) are important reservoirs and highly probable vectors for the spread of infection into domestic animals and humans. During the hunting season, hunting dogs are often in direct or indirect contact with wild animals that could be carriers of this disease, and the possibility of appearance and spreading within this cohort of dogs is very high. The main reasons for this study on the prevalence of Leptospirosis in Bosnia and Herzegovina are the regular contact between hunting dogs and wild animals (carriers), and the lack of data about Leptospirosis in hunting dogs. In total, 175 serum samples from 15 towns of
\end{abstract}

Bosnia and Herzegovina were tested. Twelve serovars of $L$. interrogans were used in the microscopic agglutination test. Presence of antibodies of four serovars was confirmed. Prevalence of seropositive dogs was $15.4 \%$ (27/175). Most positive dogs had a reaction to the Pomona serovar $51.8 \% \quad(n=14)$, while the prevalence of the Sejroe serovar was $33.3 \%$, Icterohaemorrhagiae serovar $11.1 \%$ and Bratislava serovar $3.7 \%$. The highest number of positive reactions $55.5 \% \quad(n=15)$ was with serum dilution of 1:200. This study showed that most infections in dogs were caused by serovars that are currently not included in commercial vaccines. One of the most efficient preventive measure could be vaccination with the serovars most often found in wild animals, as they appear to be the most common source of the infection.

Key words: leptospirosis; serovars; prevalence; hunting dogs

Amel ĆUTUK ${ }^{*}$, DVM, PhD, Assistant Professor, (Corresponding author, e-mail: amel.cutuk@vfs.unsa. ba), Benjamin ĆENGIĆ, DVM, PhD, Assistant Professor, Lejla VELIĆ, DVM, PhD, Assistant Professor, Ermin SALJIĆ, DVM, PhD, Assistant Professor, Pamela BEJDIĆ, DVM, PhD, Assistant Professor, Veterinary Faculty, University of Sarajevo, Sarajevo, Bosnia and Herzegovina; Alenka DOVČ, DVM, PhD, Full Professor, Renata LINDTNER KNIFIC, DVM, PhD, Full Professor, Faculty of Veterinary Medicine University of Ljubljana, Ljubljana, Slovenia 


\section{Introduction}

Leptospirosis is acute, subacute or chronical septicaemia disease that affects a many domestic animal species (Alton et al., 2009), wild animals and humans (Heuter et al., 2003). It is caused by different serovars (sv) of Leptospira (L.) interrogans sensulato (Brown et al., 1996). The disease is widespread around the world. Due to its high forest cover, large water bodies and favourable climate, Bosnia and Herzegovina is a natural habitat for Leptospirosis, with wild forest animals as the main reservoir, thus enabling the disease to be sustainable in nature.

The dog is the primary host for sv. Canicola, and sv. Icterohaemorrhagiae, although they are also known to be affected by other serovars (Pomona, Sejroe, Autumnalis, Grippotyphosa, Bratislava, Australis, Bataviae, etc.; Goldstein, 2005; Habus et al., 2017), for which they are a secondary or random host. These serovars have also been found in wild animals, including wild boar, fox or wolf (Ribotta et al., 2000). Previous studies on the presence of Leptospirosis in dogs demonstrated that in urban areas, the disease is commonly caused by the serovars Canicola and Icterohaemorrhagiae, while in suburban and rural areas, the dominant serovars are Pomona and Grippotyphosa (Kahn and Line 2005; Habus et al., 2017).

The disease is usually endemic and sustained in a certain environment by variety of animal species, with rodents as primary reservoirs. Different animal species are maintenance hosts of distinct serovars. Domestic animals can serve as maintenance hosts (e.g. cattle for the serovar Hardjo, dogs for the serovar Canicola) or incidental hosts when infected with serovars carried by other domestic or free-living animals. In maintenance hosts, the disease is usually subclinical or mild, while in incidental hosts infection is often accompanied by the emergence of clinical signs that vary depending on the animal species and infecting serovar (Habus et al., 2017).

According to information obtained from countries in the region, foxes and wild boars are the wild animals with the greatest number of positive samples. Research conducted in Croatia by Milas et al. (2013) in the period from 2002 to 2011, tested 215 samples from wild boars and 59 samples from foxes. Leptospirae were identified using the serology method (MAT), and growth plates (Korthof and EMJH growth plate). Of the 215 wild boar samples, 75 were positive for: Australis (37.33\%), Grippotyphosa (10.67\%) and Tarassovi (6.67\%) (Milas et al., 2013). For fox, 34 of 59 samples (57.6\%) tested positive for Leptospirosis, and the most common serovar was Australis, though antibodies for the serovars Sejroe and Grippotyphosa were also detected (Milas et al., 2013). Other research in Croatia (Slavica et al., 2011) in the period 2005 to 2010 tested 358 serum samples from foxes (Vulpes vulpes) and 351 serum samples from wild boars using microscopic agglutination (MAT) to detect antibodies for antigens of 12 serotypes of Leptospirae. The data showed positive findings in 121 foxes $(33.8 \%)$, with identified antibodies for 11 serotypes (Australis, Sejroe, Icterohaemorrhagiae, Saxkoebing, Grippotyphosa, Tarassovi, Ballum, Pomona, Poi, Bataviae and Canicola). In line with previous studies, the most common serovar was Australis (32.1\%), followed by Sejroe $(18.2 \%)$ and Icterohaemorrhagiae $(13.2 \%)$. The same technique (MAT) was used to test serum samples from wild boars for the presence of specific antibodies for serovars of 12 Leptospira spp. Antibodies were found for 9 serovars of Leptospira spp.: Australis, Pomona, Tarassovi, Sejroe, Grippotyphosa, Icterohaemorrhagiae, Ballum, Saxkoebing 
and Bataviae. The most common serovar was Australis (33.3\%), followed by Pomona $(21.8 \%)$ and Tarassovi (14.3\%). Notably, significant differences were found in the prevalence rates of antibodies across age groups, with the biggest difference between piglets $(21.5 \%)$ and adult pigs (50.8\%) (Slavica et al., 2011). Milas et al. (2006) also found a high prevalence rate $(57.6 \%)$ of antibodies for different serovars of Leptospira spp. in foxes in northwest Croatia, predominantly Australis, Sejroe and Icterohaemorrhagiae, While Slavica et al. (2011) found a lower seroprevalence rate $(33.8 \%)$ in fox populations from continental Croatia, though the same serovars were found to be dominant: Australis (32.1\%), Icterohaemorrhagiae $(18.2 \%)$ and Sejroe $(13.2 \%)$. Milas et al. (2013) found that 32 of $67(46.26 \%)$ serum samples of foxes were positive, with the highest antibody titres for the serovars Australis, Sejroe, Saxkoebing and Grippotyphosa. In a wild boar population, 75 of 215 serum samples (34.88\%) were positive and the most common serovars were: Australis, Grippotyphosa and Tarassovi. Kovačić et al. (2001) conducted a study on the outspread of L. interrogans in wild animals in the Gorski Kotar area, and found serologically positive bear, wild boar, deer, wolf and marten, and the dominant serovars were Australis, Serjoe, Saxkoebing and Icterohaemorrhagiae. A study in Slovenia (Vengušt et al., 2008), found that 200 of 437 animals $(45.8 \%)$ were positive for one or more Leptospirosis serovars, with Tarassovi as the most common serovar.

Given the continual increase in the wild animal population in Bosnia and Herzegovina and their proximity to inhabited areas, it becomes clear that monitoring of Leptospirosis in wild animals can have a preventive impact on the presence of this disease among domestic animals and humans. Since the wild boar population is increasing, as are foxes having feeding habits similar to rodents, which are well known reservoir of Leptospirosis, future measures to prevent the spread of this disease to other wild and domestic species should be focused on these species.

The aim of the current study was to establish the presence of antibodies for Leptospira in a hunting dog population throughout Bosnia and Herzegovina. Hunting dogs are often in contact with wild animals, mainly wild boars and foxes, thus playing a key role in the wider chain of the Leptospirosis spread. Therefore, it is necessary to determine their status as reservoirs, but also the role they play as potential vectors in transmitting this disease from wild animals to dogs and finally humans.

\section{Materials and methods}

Laboratory testing was performed at the Faculty of Veterinary Medicine, University of Sarajevo in the Laboratory for Virology and Serology and Department for Internal Diseases, and at the Faculty of Veterinary Medicine, University of Ljubljana (Slovenia) in the Laboratory for Leptospirosis within the Institute for Poultry, Birds, Small Mammals and Reptiles.

Data collection was conducted during 2014 and 2015. In total 175 dogs (137 male and 38 females) from 15 cities in Bosnia and Herzegovina were part of the final sample. The cities were: Bihać, Bijeljina, Busovača, Foča, Goražde, Jablanica, Ključ, Konjic, Lukavac, Prijedor, Sanski Most, Sarajevo, Travnik, Tuzla and Zenica. All dogs were between 1 to 7 years old. Clinical examinations were performed before sampling of biological materials. Anamnestic data analysed included symptoms related to disease or infections such as fever, anaemia, yellowness of visible mucous membranes, muscle soreness, vomitus, pathology of urinary system and vaccination status. 
A total of 350 blood serum samples of biological materials were tested. All sampling complied with animal welfare protocols (Official Journal of Federation 316/09), and verbal or written permission was obtained from the dog owners.

Blood and blood serum were taken from animals via a punctuation of venae cephalica antebrachia, ensuring aseptic and antiseptic conditions. Vacutainer tubes with ethylene diamine tetraacetate (EDTA) were used for serology assessment. Tubes with whole blood intended for serology assessment were centrifuged at $1500 \mathrm{x}$ g for 10 minutes. Serum was later separated into cryotubes and stored in the freezer at $-20{ }^{\circ} \mathrm{C}$ until testing.

The microscopic agglutination test (MAT) was used for serology testing assessment according to OIE manual for the serotypes: Grippotyphosa, Canicola, Sejroe, Pomona, Tarassovi, Icterohaemorrhagiae, Australis, Autumnalis, Bratislava, Bataviae, Saxkoebing and Hardjo.

Test was performed in two stages. The first phase (preliminary testing) was to determine the presence of specific antibodies for the specified serovars of pathogenic leptospira. The reaction was declared positive if more than $50 \%$ of agglutinating leptospires were present in the field of view. In the second phase, the titre of the specific antibodies in the tested serums was assessed, where the final titer was the highest serum dilution in which $50 \%$ agglutination could be observed.

All raw data obtained was transferred from the MS Excel program, SPSS v.20.0. statistical program. SPSS was used for calculation of basic descriptive statistics, questionnaires, MAT results for detection of specific antibodies. To determine differences in the presence of antibodies for certain serovar in each of the three assessed categories, chi-squared $\left(\chi^{2}\right)$ analysis was carried out.

\section{Results}

All dogs in the study were in good health condition and most were vaccinated (Table 1). General clinical examination revealed certain pathology in $9.1 \%(16 / 175)$ of dogs, mostly in relation to their respiratory system, eyes/ nasal discharge and finally digestive and urinary disorders (Figure 1).

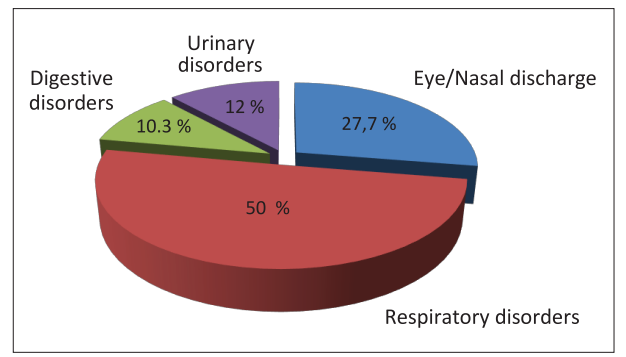

Figure 1. Observed pathological conditions in 16 dogs

According to the medical history of all dogs in the study, most had been vaccinated with a bivalent vaccine (Icterohaemorrhagiae and Canicola), commonly used as a prevention measure.

Seroprevalence was determined to be $15.4 \%$ (27/175). After serotyping in different dilutions, the most positive reactions were found for sv. Pomona $51.8 \%(14 / 27)$, then sv. Sejroe $33.3 \%$ (9/27), sv. Icterohaemorrhagiae $11.1 \%(3 / 27)$ and sv. Bratislava (3.7\%) (Figure 2). No

Table 1. Ratio of vaccinated and non-vaccinated dogs in study.

Total number of dogs

$n=175$
Vaccinated

$146(83.4 \%)$
Non-vaccinated

$29(16.4 \%)$ 
positive reactions were found for the serovars: Canicola, Grippotyphosa, Australis or Autumnalis. If one sample was positive for two or more leptospira antigens, the serovar with highest titer was considered the infective agent.

Three animals showed a positive reaction in the dilution 1:50, eight in the dilution 1:100, and 15 in the dilution 1:200. The final dilution 1:400 showed a positive reaction for sv. Pomona in only one dog.

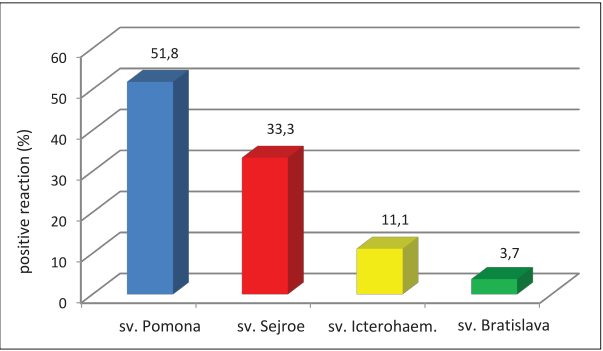

Figure 2. Seroprevalence and serotyping of positive animals

\section{Discussion and conclusions}

There is limited knowledge on the presence of Leptospirosis in hunting dogs in Bosnia and Herzegovina. Maintenance of this disease in nature is enabled by circulation of causative agents between wild and domestic animals. Wild animals, primarily rodents, foxes and wild boars are potential source of infection for other wild (Hathaway et al., 1981, 1983; Kovačić et al., 2001) and domestic animals (Alton et al., 2009), and for humans (Heuter et al., 2003).

The most common serovars detected in hunting dogs in this study were Pomona, Sejroe, Icterohaemorrhagiae and Bratislava. The highest seroprevalence was found for sv. Pomona in more than half of positive animals (51.8\%). Likewise, the highest titres of antibodies (1:400) were found for sv. Pomona. These data support the findings of Štritof Majetić et al., (2012) in Croatia and Marić et al. (2012) in Serbia, who also identified high prevalence rates for sv. Pomona. In line with their conclusions, our results match the findings that most infections in dogs were caused by serovars not included in commercial vaccines.

These results can be explained by the close proximity and frequent contact between dogs and domestic and wild pigs, as the most common carriers for sv. Pomona. This serovar is found in wild boars in Croatia (26\%; Cvetnić et al., 2003), and in Slovenia (45\%; Vengušt et al., 2008). Infection is assumed to most likely be effused via ground ploughing, where tunnels are made by rodents and/ or by rodent consumption. However, the possibility of infection from ruminants should not be excluded. According to Habus et al. (2017), seroreactivity was high in cattle $(8.07-22.66 \%$, average $14.34 \%$ ) with most positive reactions with sv. Sejroe, although an increase of infections with Grippotyphosa and Pomona was noted in 2014. Small ruminants however, have a very low seroprevalence $(0.64-3.58 \%$, average $0.90 \%)$ mostly with Pomona, Sejroe and Grippothyposa (Habus et al., 2017).

The second most common serovar identified was sv. Sejroe. A possible cause for this could be the fact that mouselike rodents are the main reservoir of the serovars Australis and Sejroe, as they form the basis of the fox diet (Milas et al., 2006) and are known natural reservoirs of Leptospirosis in Bosnia and Herzegovina, and elsewhere. It is likely that this is one of the real foundations for transmission of causative agents within the wild animal food web and finally to hunting dogs.

The obtained percentages for vaccine serovars are relatively low, although they are only one of the indicators of immune protection against Leptospirosis. Klaasen et al. (2003) reported that immunisation can prevent highly expressed clinical signs of the disease, but not the infection 
itself. Appropriate immunisation consists of three to four vaccinations at intervals of two to three weeks, and immunity usually lasts six to eight months, which is important for restoration of immunity, especially if dogs are in contact with aquatic areas. Although the pathogenesis of the disease is well documented, the cellular and molecular processes are still unclear. Attenuated vaccines are licenced throughout the world but have changed much in the past few decades. Immunity provided by a vaccine is limited to serologically connected serovars and it usually has a short duration, which requires revaccination (Klaasen and Adler, 2015). Researchers have established that unlike virus vaccines, bacterial vaccines do not produce immunity that lasts 12 months or more, therefore it is recommended that vaccination is repeated in shorter time intervals. Inactivated vaccines with the serovars Canicola and Icterohaemorrhagiae are mostly used in Europe (AndreFontaine, 2006), while in North America, vaccines contain four attenuated serovars: Icterohaemorrhagiae, Canicola, Pomona and Grippotyphosa (Claus et al., 2008).

The total seroprevalence of $15.4 \%$ detected here, in conjunction with the data of other authors shows that vaccination with bivalent vaccines containing the serovars Icterohaemorrhagiae and Canicola as a preventive measure for protection against Leptospirosis in the hunting dog population in Bosnia and Herzegovina has not produced satisfactory results, despite revaccination at regular intervals. The high percent of sv. Pomona seropositive animals shows that another specific and non-specific preventive measure should be implemented to combat the spread of this disease among dog populations. One of the most efficient preventive measures is vaccination with polyvalent vaccines including the serovars Icterohaemorrhagiae, Canicola, Pomona and Grippotyphosa. Likewise, a multidisciplinary approach to the control and prevention of Leptospirosis, especially conducting veterinary control and eradication of Leptospirosis in different wild and domestic species as potential sources of infection, are highly important. Since Bosnia and Herzegovina has many free roaming dogs that come into contact with other animals and humans, ongoing serological research into populations of domestic carnivores should be imposed as a mandatory precautionary measure to suppress Leptospirosis.

\section{References}

1. ALTON, G. D., O. BERKE, R. REID-SMITH, D. OJKIC and J. F. PRESCOTT (2009): Increase in seroprevalence of canine leptospirosis and its risk factors, Ontario 1998-2006. Can. J. Vet. Res. 73, 167-175.

2. ANDRE-FONTAINE, G. (2006): Canine leptospirosisdo we have a problem? Vet. Microbiol. 117, 19-24.

3. BROWN, C. A., A. W. ROBERTS, M. A. MILLER, D. A. DAVIS, S. A. BROWN, C. A. BOLIN, J. JARECKI-BLACK, C. E. GREENE and D. MILLERLIEBL (1996): Leptospira interrogans serovar grippotyphosa infection in dogs. J. Am. Vet. Med. Assoc. 209, 1265-1267.

4. CLAUS, A., I. VAN De MAELE, F. PASMANS, K. GOMMEREN and S. DAMINET (2008): Leptospirosis in dogs: a retrospective study of seven clinical cases in Belgium. Vlaams Diergeneeskundig Tijdschrift 77, 259-263.

5. CVETNIĆ, Z., J. MARGALETIĆ, J. TONČIĆ, N. TURK, Z. MILAS, S. SPIČIĆ, M. LOJKIĆ, S. TERZIĆ, L. JEMERŠIĆ, A. HUMSKI, M. MITAK, B. HABRUN and B. KRT (2003): A serological survey and isolation of leptospires from small rodents and wild boars in the Republic of Croatia. Vet. Med. 48, 321-329.

6. GOLDSTEIN, R. E. (2005): Canine leptospirosis. In: Proceedings $15^{\text {th }}$ ECVIM-CA Congress, Glasgow. Pp. 84-87.

7. HATHAWAY, S. C., D. K. BLACKMORE and R. B. MARSHALL (1981): Leptospirosis in free-living species in New Zealand. J. Wildl. Dis. 17, 489-496.

8. HATHAWAY, S. C., T. W. A. LITTLE, S. A. HEADLAM and A. E. STEVENS (1983): Infection of free-living carnivores with leptospires of the Australis serogroup. Vet. Rec. 113, 233-235.

9. HEUTER, K., J. KERRY, C. LANGSTON and E. CATHY (2003): "Leptospirosis: A re-emerging zoonotic disease". Vet. Clin. N. Am. 33, 791-807.

10. HABUS, J., Z. PERSIC, S. SPICIC, S. VINCE, Z. STRITOF, Z. MILAS, Z. CVETNIC, M. PERHARIC and N. TURK (2017): New trends in human and animal leptospirosis in Croatia, 2009-2014. Acta Trop. 168, 1-8.

11. KAHN, C. and S. M. LINE (2005): Leptospirosis in dogs. In: The Merck Veterinary Manual, $9^{\text {th }}$ edn. 
Merck \& Co., Inc., Whitehouse Station, N.J., USA. Pp. 525-529.

12. KLAASEN, H. and B. ADLER (2015): Recent advances in canine leptospirosis: focus on vaccine development. Vet. Med. Res. Rep. 6, 245-260.

13. KLAASEN, H. L., M. J. MOLKENBOER, M. P. VRIJENHOEK and M. J. KAASHOEK (2003): Duration of immunity in dogs vaccinated against leptospirosis with a bivalent inactivated vaccine. Vet. Microbiol. 95, 121-132.

14. KOVAČIĆ, H., M. KARLOVIĆ i A. FRKOVIĆ (2001) Istraživanje proširenosti protutijela za Leptospiru interrogans u divljači na području Gorskog kotara. Vet. stn. 32, 69-77.

15. MARIĆ, J., M. ELEZOVIĆ, D. VOJINOVIĆ, M. MILOVANOVIĆ, I. ZARIĆ i B. ĐURIČIĆ (2012) Ispitivanje prisustva različitih serotipa leptospira u populaciji lovačkih pasa u zapadnoj Srbiji. U: Međunarodni simpozijum o lovstvu, "Savremeni aspekti održivog gazdovanja populacijama divljači«, Zemun-Beograd, Srbija, 22.-24. juni 2012, Zemun-Beograd, Srbija, pp. 137-139.

16. MILAS, Z., N. TURK, Z. JANICKI, A. SLAVICA, V. STAREŠINA, Lj. BARBIĆ, M. LOJKIĆ and Z. MODRIĆ (2006): Leptospiral antibodies in red foxes (Vulpes vulpes) in northwest Croatia. Vet. arhiv 76, 51-57.
17. MILAS, Z., Z. ŠTRITOF MAJETIĆ, J. HABUŠ, V. MOJČEC PERKO, V. STAREŠINA, Lj. BARBIĆ, V. STAREŠINA, V. STEVANOVIĆ, M. PERHARIĆ, B. LJUBIĆ and N. TURK (2013): The occurrence and maintenance of he occurrence and maintenance of Leptospira eptospiraserovars Australis and serovars Australis and Bratislava in domestic and wild animals in Croatia. Vet. arhiv 83, 357-369.

18. RIBOTTA, M., M. FORTIN, R. HIGGINS and S. BEAUDIN (2000): Canine leptospirosis: serology. Can. Vet. J. 41, 494-495.

19. SLAVICA, A., D. DEŽDEK, D. KONJEVIĆ, Ž. CVETNIĆ, M. SINDIČIĆ, D. STANIN, J. HABUŠ and N. TURK (2011): Prevalence of leptospiral antibodies in red fox (Vulpes vulpes) population from Croatia. Vet. Med. 56, 209-213.

20. ŠTRITOF MAJETIĆ, Z., J. HABUŠ, Z. MILAS, V. MOJČEC PERKO, V. STAREŠINA and N. TURK (2012): A serological survey of canine leptospirosis in Croatia - the changing epizootiology of the disease. Vet. arhiv 82, 183-191.

21. VENGUŠT, G., R. LINDTNER-KNIFIC, D. ŽELE and A. BIDOVEC (2008): Leptospira antibodies in wild boars (Sus scrofa) in Slovenia. Eur. J. Wildl. Res. 54, 749-752.

\section{Istraživanje prisustva različitih serovarova Leptospirae Interrogans u lovačkih pasa u Bosni i Hercegovini}

Dr. sc. Amel ĆUTUK, dr. med. vet., docent, dr. sc. Benjamin ČENGIĆ, dr. med. vet., docent, dr. sc. Lejla VELIĆ, dr. med. vet., docentica, dr. sc. Ermin ŠALJIĆ, dr. med. vet., docent, dr. sc. Pamela BEJDIĆ, dr. med. vet., docentica, Veterinarski fakultet Univerziteta u Sarajevu, Sarajevo, Bosna i Hercegovina; dr. sc. Alenka DOVČ dr. med. vet., redovita profesorica, dr. sc. Renata LINDTNER KNIFIC, dr. med. vet., redovita profesorica, Veterinarski fakultet Univerzitet u Ljubljani, Ljubljana, Slovenija

Leptospiroza je akutna, subakutna i kronična zarazna bolest životinja i ljudi. Uzročnici ove bolesti pripadaju rodu Leptospira, porodici Leptospiraca. Leptospiroza kao bolest divljih životinja široko je rasprostranjena $u$ Europi. Određene divlje životinje (glodavci, lisice i divlje svinje) kao važan rezervoar i vrlo vjerojatan vektor zaraze proširile su bolest na domaće životinje i ljude. Lovački psi tijekom sezone lova često su u direktnom ili indirektnom kontaktu s divljim životinjama koje bi mogle biti nositelji ove bolesti, a mogućnost pojave i širenja unutar kategorije takvih pasa vrlo je velika. Glavni razlozi ove studije o učestalosti leptospiroze na području Bosne i Hercegovine su redoviti kontakti lovačkih pasa i divljih životinja (nositelji) i nedovoljni podatci o prisutnosti leptospiroze u kategoriji lovačkih pasa. Ukupno je istraženo 175 uzoraka seruma iz 15 gradova
Bosne i Hercegovine. U mikroskopskom testu aglutinacije korišteno je dvanaest serovara $L$. Interrogans. Potvrđena je prisutnost antitijela na četiri serovara. Prevalencija seropozitivnih pasa bila je 15,4 \% (27/175). Većina pozitivnih pasa imala je reakciju na serovar Pomona 51,8 \% $(n=14)$, dok je u serovaru Sejroe prevalencija $33,3 \%$, serovar Icterohaemorrhagiae 11,1 \% i serovar Bratislava 3,7\%. Najveći broj pozitivnih reakcija bio je s razrjeđivanjem seruma od 1:200 ili 55,5\% ( $n=15)$. Studije pokazuju da su većinu infekcija u pasa prouzročili serovari koji nisu uključeni u komercijalna cjepiva. Jedna od najučinkovitijih preventivnih mjera mogla bi biti cijepljenje sa serovarovima koji se najčešće nalaze u divljih životinja jer su one najčešći izvor zaraze.

Ključne riječi: leptospiroza, serovari, prevalencija, lovački psi 